\title{
Calcareous Nannofossils Biostratigraphy of Shiranish Formation (K-306) well, Northern Iraq
}

Maryam Abdul-Rheem Al-Maamari

Omar Ahmed Al-Badrani

\author{
Dept. of Geology \\ College of Science \\ Mosul University
}

(Received 7/ 4 /2019 , Accepted $25 / 7 / 2019)$

\begin{abstract}
Twenty Samples of Shiranish Formation from the well (K-306), Kirkuk area, northern Iraq, are collected and studied on the basis of stratigraphic ranges of the recorded calcareous nannofossils. Eighty-nine species in the studied section reveals five biozones arranged from oldest to youngest as follows:

1.Quadrum trifidum Interval Biozone (CC22) Part

2.Tranolithus phacelosus Interval Biozone (CC23)

3.Rienhardtites lives Interval Biozone (CC24)

4. Arkhangelskilla cymbiformis Interval Biozone (CC25)

5. Nephrolithus frequens Rang Biozone (CC26) Part

These Biozones are correlated with other calcareous nannofossils biozones, from both local and regional sections, leading to conclude the age of CampanianMaastrichtian.

Keywords: Calcareous nannofossils, Biostratigraphy, Cretaceous, Iraq.

$$
\begin{aligned}
& \text { الطباقية الحياتية لمتحجرات النانو الكلسية لتكوين شرانش في بئر (K-306)، شمالي } \\
& \text { العراق } \\
& \text { عمر أحمد البدراني } \\
& \text { مريم عبد الرحيم المعماري } \\
& \text { قسم علوم الأرض كل } \\
& \text { كلية العلوم } \\
& \text { جامعة الموصل كلوم } \\
& \text { الملخص }
\end{aligned}
$$

1-Quadrum trifidum Interval Biozone (CC22) Part

2-Tranolithus phacelosus Interval Biozone (CC23). 


\section{3-Reinhardtites levis Interval Biozone (CC24)}

4-Arkhangelskilla cymbiformis Interval Biozone (CC25)

5-Nephrolithus frequens Rang Biozone (CC26) Part

تمت مضاهاة الأنطقة الحالية مع الأنطقة المحلية والعالمية، وأستتنج عمر التكوين بالكامبانيان المتأخر -

الماسترختيان.

الكلمات الالة: متحجرات النانو الكلسية، طباقية حياتية، العصر الطباشيري، العراق.

\section{INTRODUCTION}

Shiranish Formation was first described in (Shiranish Islam, near Zakho, northern Iraq, the type section that appears in outcrops immediately above and below the village, lat. $\left(31^{\circ} 11^{\prime} 32^{\prime \prime N}\right.$.), long. (42 $50^{\prime} 30^{\prime \prime E}$.)) The thickness is 227.8 meters (Bellen et al., 1959).

The studied section lies in Kirkuk area at (K-306) (lat. 35 50'50"N.) and (long. $43^{\circ} 40^{\prime} 28 ' \mathrm{E}$.), it consists of limestone and marly limestone between depths (15501670) $\mathrm{m}$., so the thickness is about (120) m. (Fig.1). Shiranish Formation aged Campanian to Masstrichtian in Ba. (8) well (Al-Badrani and Al-Assaf, 2011) and by Campanian for the lower unit in Sinjar anticline.(Al-Badrani,2012), Al-Wazan (2013) aged Late Campanian to Masstrichtian for studied section by planktonic Foraminifera.

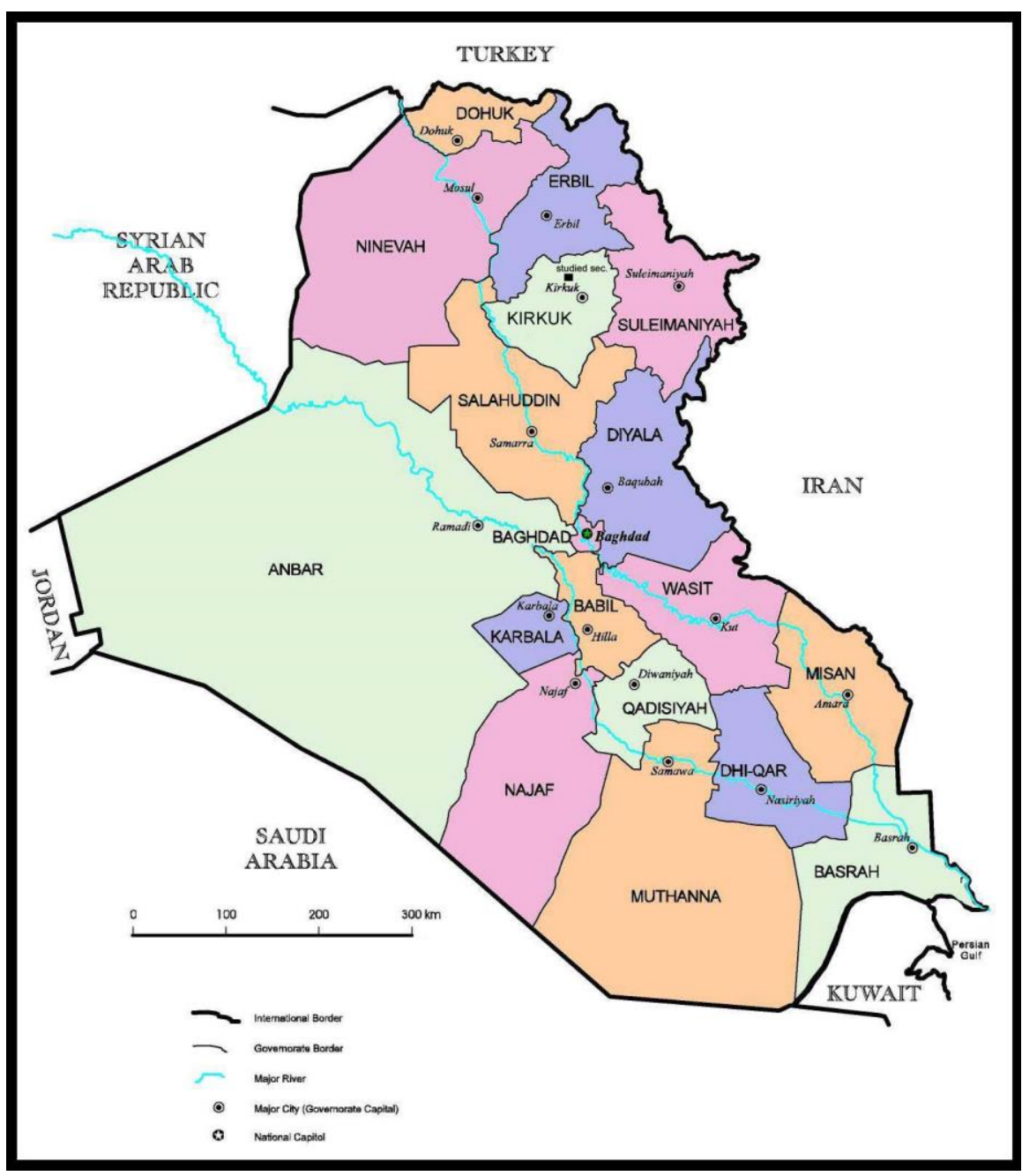

Fig. 1: Location map for the studied section at K- 306. 


\section{MATERIALS AND METHODS}

Twenty samples of limestone and marly limestone are selected for studying the calcareous nannofossils using the thin sections (under transmitted- light microscope). The calcareous nannofossils are extracted by using the method $(\mathrm{H})$ given by Armstrong and Brasier (2005).

\section{NANNOBIOSTRATIGRAPHY}

Depending on the stratigraphic distribution of the recorded species, five biozones are identified as Murphy and Salvador, 1999. (Fig. 2).

\section{1-Quadrum trifidum Interval Part Biozone (CC22) Part}

Definition: Interval biozone of Quadrum trifidum (Stradner in Stradner and Papp, 1961) Prins and Perch-Nielsen in Manivit et al. 1977.

Boundaries: the biozone determinate from first occurrence of Quadrum trifidum (Stradner in Stradner and Papp, 1961) Prins and Perch-Nielsen in Manivit et al. 1977, to the last occurrence of species Eiffilithus eximus (Stover, 1966) Perch- Nielsen, 1968, (Fig. 2).

Thickness: from (1663-1670m.) (7 m.).

Correlation and Discussion: This biozone is correlated with Zone CC22 (Quadrum trifidum zone) of Sissingh, 1977 in the late Campanian. . and correlated UC15 biozone which is studied by Burrnet in Bown (1998), which aged late Campanian age. (Gradstein et al., 2012) (Fig. 2).

\section{2- Tranolithus phacelosus Interval Biozone (CC 23)}

Definition: Interval biozone of Tranolithus phacelosus Stover, 1966.

Boundaries: The biozone determinate by last occurrence Eiffilithus eximus (Stover, 1966) Perch- Nielsen, 1968, to the last occurrence Tranolithus phacelosus Stover, 1966.

Thickness: from (1663- 1640m.) (23 m.)

Correlation and Discussion: This biozone is correlated with CC23 (Tranolithus phacelosus biozone) which studied by the Sissnghii (1977) wich aged of the late Campanian - early Maasterchtian. and correlated UC16, UC17 biozone which is studied by Burrnet in Bown (1998) wich aged Campanian-early Maastrichtian, age. (Gradstein et al., 2012), (Fig.2).

\section{3- Reinhardtites levis Interval Biozone (CC24)}

Definition: Interval biozone of Reinhardtites levis Prins and Sissingh in Sissingh, 1977.

Boundaries: The biozone determinate by Last occurrence Tranolithus phacelosus Stover, (1966) to the last occurrence Reinhardtites levis Prins and Sissingh in Sissngh, 1977

Thickness: from $(1640-1610 \mathrm{~m}).(30 \mathrm{~m}$.

Correlation and Discussion: This biozone is correlated with CC24 (Reinhardtites levis biozone) which studied by the Sissnghii (1977) at the age of the late Campnian - early Maastrichtian. and correlated UC18 biozone which is 
studied by Burrnet in Bown (1998) which aged Maastrichtian age. (Gradstein et al., 2012), (Fig. 2).

\section{4- Arkhangelskiella cymbiformis Interval Biozone (CC25)}

Definition: Interval biozone of Arkhangelskiella cymbiformis Vekshina, 1959

Boundaries: The biozone determinate by last occurrence Reinhardtites levis Prins and Sissingh in Sissngh, (1977) to the first occurrence Nephrolithus frequens Górka, (1957).

Thickness: from (1610-1580m.) (30 m.).

Correlation and Discussion: This biozone is correlated with (CC25) (Arkhangelskiella cymbiformis Biozone) Sissingh, (1977) and divided into three subdivisions (CC25a, CC25b, CC25c) by the first appearance of the species Arkhangelskiella cymbiformis and the first appearance of species Lithraphidites quadratus at Maastrichtian age, and correlated UC19 biozone which is studied by Burrnet in Bown (1998) which aged Late Maastrichtian age. (Gradstein et al., 2012) (Fig.2).

\section{5-Nephrolithus frequens Rang Biozone (CC26) Part}

Definition: Rang biozone of Nephrolithus frequens Górka, (1957).

Boundaries: The biozone determinate by first occurrence to the last occurrence of Nephrolithus frequens Górka, (1957).

Thickness: from (1580-1550m.) (30 m.).

Correlation and Discussion: This biozone is correlated with Nephrolithus frequens biozone (CC26) which aged Late Maastrichtian Sissingh, (1977), and correlated UC20 biozone which is studied by Burrnet in Bown (1998) which aged Late late Maastrichtian age. (Gradstein et al., 2012), (Fig. 2).

\section{CONCLUSIONS}

Shiranish Formation in (K-306) well consists of biozones for calcareous nannofossils, these are from older to younger (Figs. 2 and 3):

1.Quadrum trifidum Interval Biozone (CC22) Part

2.Tranolithus phacelosus Interval Biozone (CC23)

3.Rienhardtites lives Interval Biozone (CC24)

4. Arkhangelskilla cymbiformis Interval Biozone (CC25)

5. Nephrolithus frequens Rang Biozone (CC26) Part

This biozones aged Late Campanian- Maastrichtian for studied section 


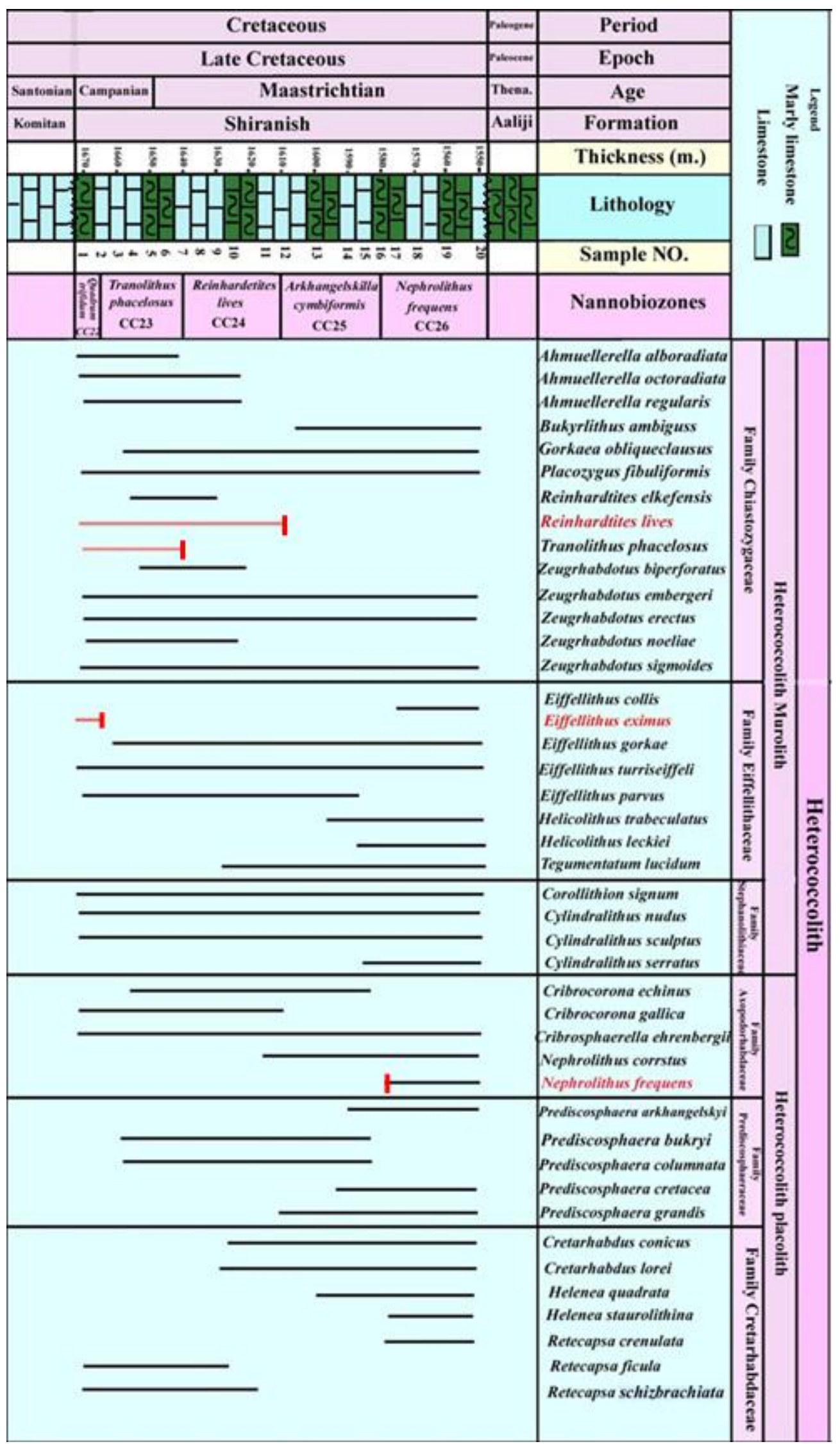

Fig 2a: Biostratigraphic chart of studied section 


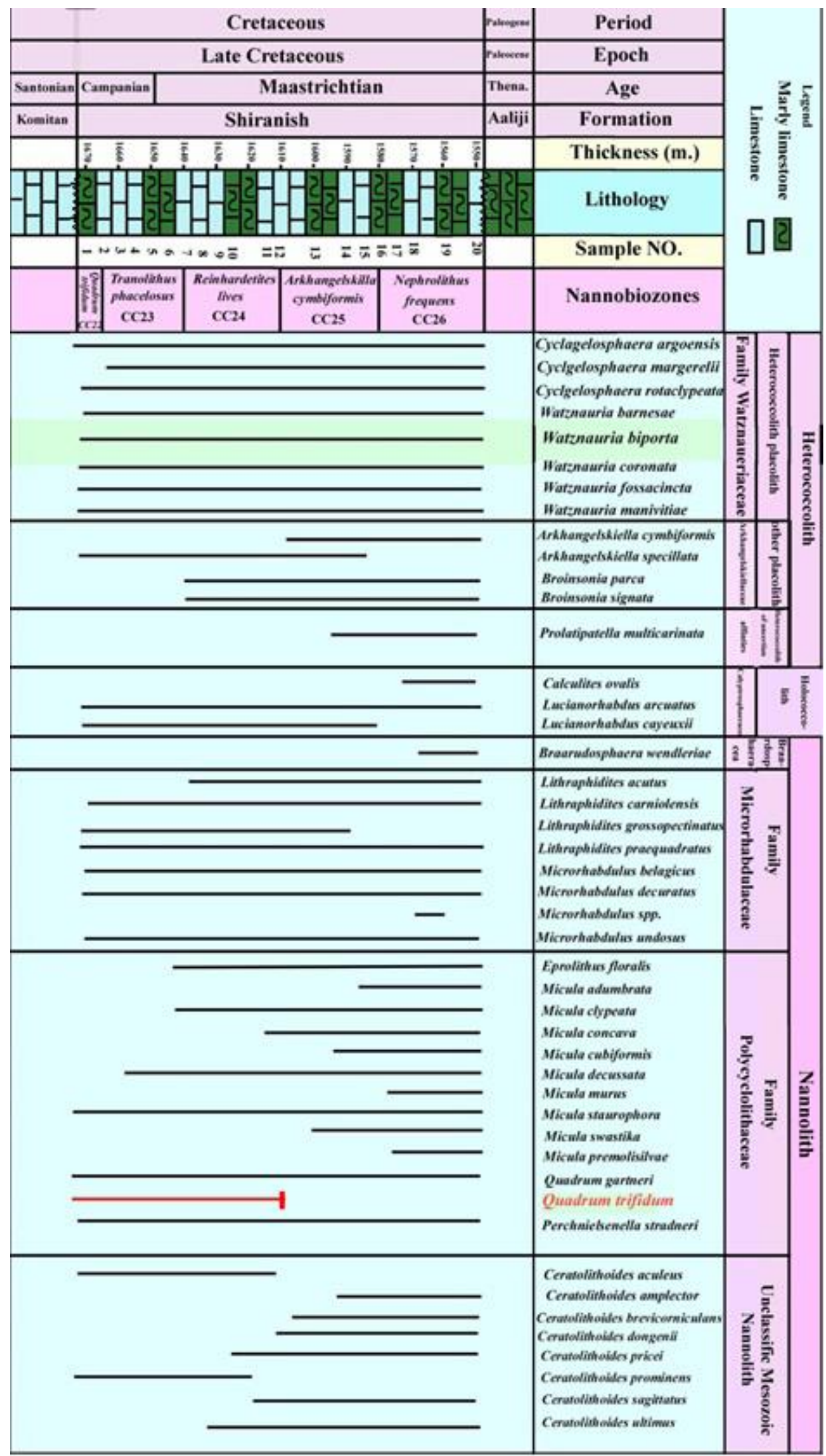

Fig. 2b: Biostratigraphic chart of studied section 
Calcareous Nannofossils Biostratigraphy of Shiranish Formation (K-306) well.... 7

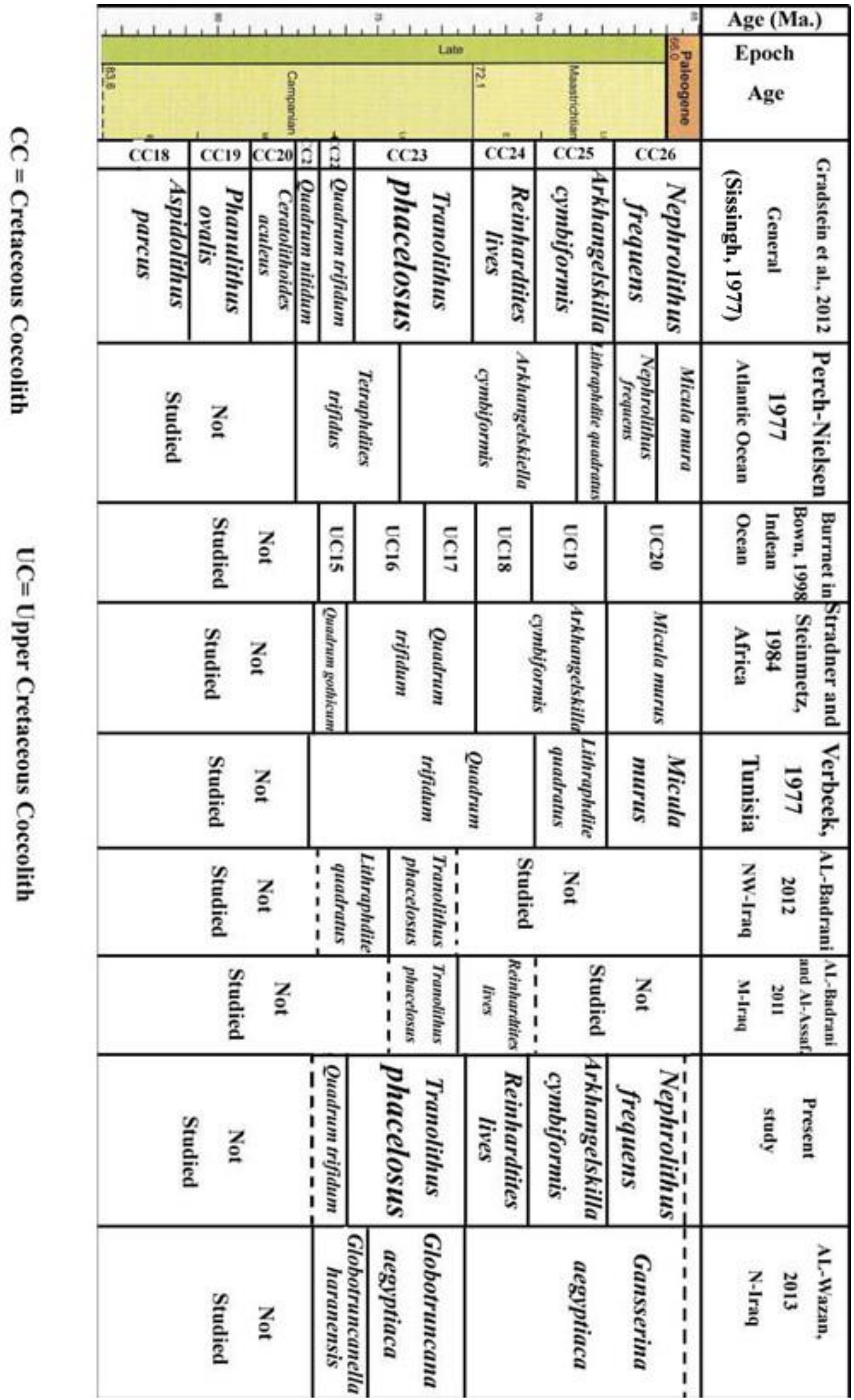

Fig. 3: Comparison between the calcareous nannofossils biozones for the studied section. 


\section{REFERENCES}

Armstrong, H. and Brasier, M. ,2005. Microfossils Black well publishing., p. 296.

Al-Badrani, O. A., 2012. Nannobiostratiraphy of the Lower part of Shiranish Formation, Sinjar Anticline, NW Iraq. Iraqi National Journal of Earth Sciences, vol. 12, no. 1, pp. 1-16.

Al-Badrani, O. A., and Al-Assaf, E. N.,2011. Nannobiostratigraphy of Shiranish Formation in Balad Well No. 8, Northern Baghdad, Iraq. Iraqi National Journal of Earth Sciences, vol. 11, no. 2, pp. 65-80.

Bellen, R.C. Van, Dunnington, H.V ., Wetzel, R. and Morton , D. M. 1959. Lexique stratigraphique international, V.III: Asie, Fascicule 10 a, Iraq. 333 p.

Burnett, J.A.,1998. Upper Cretaceous. In: Bown, P.R. (Editor), Calcareous Nannofossil Biostratigraphy. British Micropalaeontological Society Publications Series. Chapman and Hall, London, pp. 132-199.

Gradstein, F. M., Ogg, J. G., Schmitz, M. D. and Ogg, G., M.,2012. The geologic time scale. The Boulevard, Langford lane, Kidlington, Oxford OX5 1GB, UK, vol. 2, pp. 437-1144.

Górka, H.,1957. Les coccolithophoridés du Maastrichtien supérieur de pologne. Acta Palaeont. Polonica, vol. 2, no. 2-3, pp. 235-284

Manivit, H., Perch-Nielsen, K., Prins, B. and Verbeek, J.W.,1977. Mid Cretaceous calcareous nannofossil biostratigraphy. Proceedings of the Koninklijke Nederlandse Akademie van Wetenschappen, B80(3), pp. 169-181.

Murphy, A. M. and Salvador, A.,1999. International Subcommission on Stratigraphic Classification of IUGS International Commission on Stratigraphy, vol. 22, no. 4, pp. 255-272.

Perch-Nielsen, K.,1968. Der feinbau und die klassifikation der coccolithen aus dem Maastrichtien von Danemark. Kong. Danske videnskab. Selskab., Biol. Skr., vol. 16, pp. 1-96.

Perch-Nielsen, K.,1977. Albian to Pleistocene calcareous nannfossils from the western South Atlantic, DSDP Leg 39, Intial Rep. Deep Sea drilling project, 39, pp. 699-825.

Sissigh, W.,1977. Biostratigraphy of Cretaceous calcareous nannoplankton. Geol. Mjnb., vol. 56, pp. 37-65.

Stover, E.,1966. Cretaceous coccoliths and associated nannofossils from France and Netherlands. Micropaleontology, vol. 12, no. 2, pp. 133-167. 
Stradner, H. and Papp, A.,1961. Tertiäre Discoasteriden aus Österreich und deren stratigraphische Bedeutung mit Hinweisen auf Mexico, Rumanien und Italien. Jahrbuch der Geologischen Bundesanstalt (Wien), vol.7, pp. 1-159.

Stradner, H. and Steinmetz, J.,1984. Cretaceous calcareous nannofossils from the Angola Basin, Deep Sea Drilling Project Site 530. Initial Reports of the Deep Sea Drilling Project, vol. 75, pp. 565-649.

Verbeek, J. W.1977. Calcareous nannoplankton biostratigraphy of Middle and Upper Cretaceous deposites in Tunisia, Southern Spain and France. Utrecht Micropaleontology Bull., vol. 16, pp. 1-157.

Vekshina, V. N.,1959. Coccolithophoridae of the Maastrichtian deposits of the West Sberian lowland. Trudy Sibir. Nauch-Issled. Inst. Geol. Geofiz. Min. Syrya, vol. 2, pp. 56-81.

\section{PLATE 1}

1,2 Reinhardtitus levis Prins and Sissingh, in Sissingh 1977, bar = 5-micron, (1) Polarized Light Photo (2) Gypsum Light Photo.

3,4 Tranolithus phacelosus Stover, 1966, bar = 5-micron, (3) Polarized Light Photo (4) Gypsum Light Photo.

5,6 Eiffellithus eximius (Stover, 1966) Perch-Nielsen, 1968, bar = 5-micron, (5) Polarized Light Photo (6) Gypsum Light Photo.

7,8 Nephrolithus frequens Górka, 1957, bar = 5-micron, (7) Polarized Light Photo (8) Gypsum Light Photo.

9,10 Arkhangelskiella cymbiformis Vekshina, 1959, bar = 5-micron, (9) Polarized Light Photo (10) Gypsum Light Photo.

11,12 Quadrum trifidum (Stradner In Stradner and Papp 1961) Prins and PerchNielsen in Manivit et al. 1977, bar = 5-micron, (11) Polarized Light Photo (12) Gypsum Light Photo. 
PLATE 1
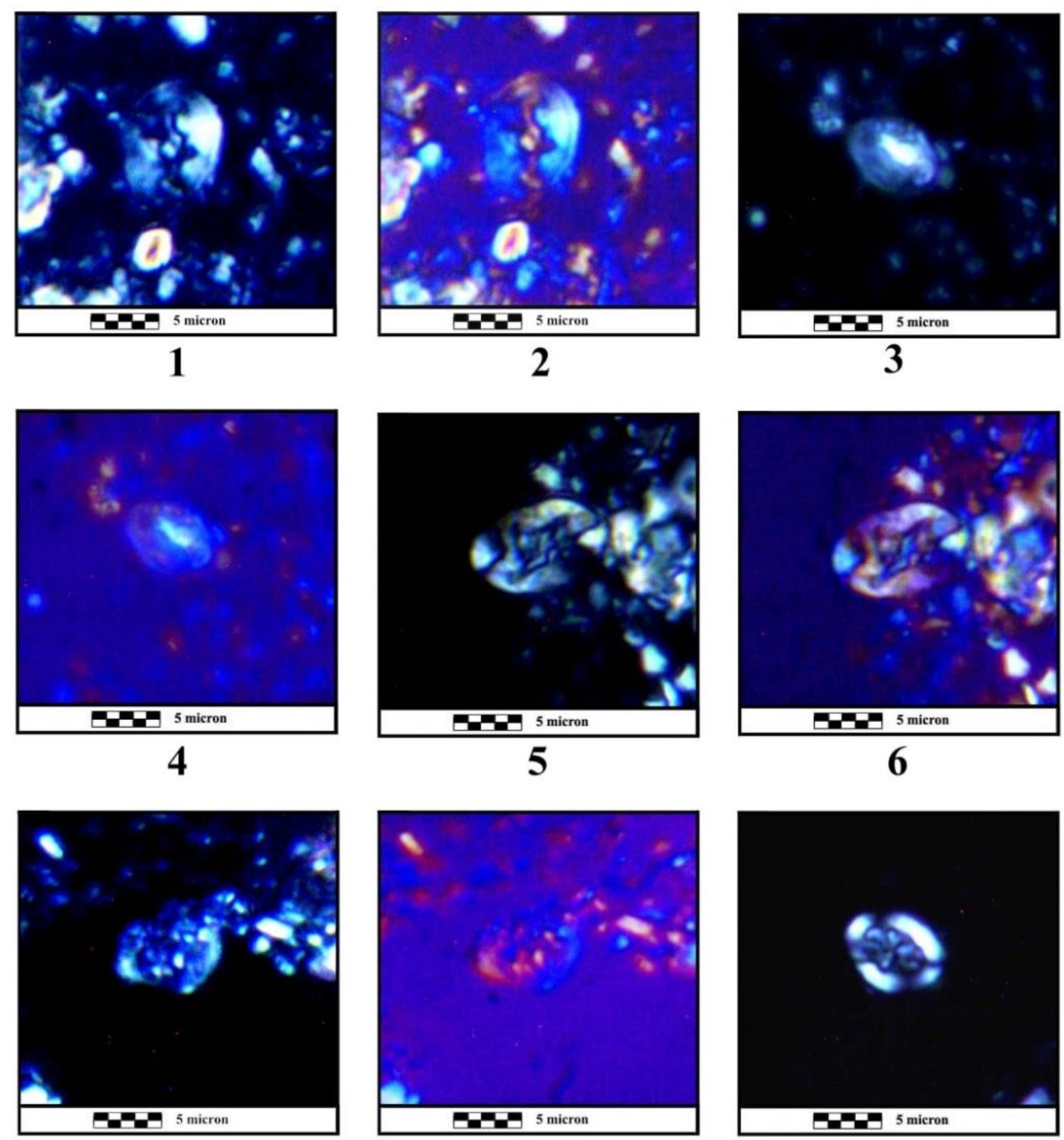

7

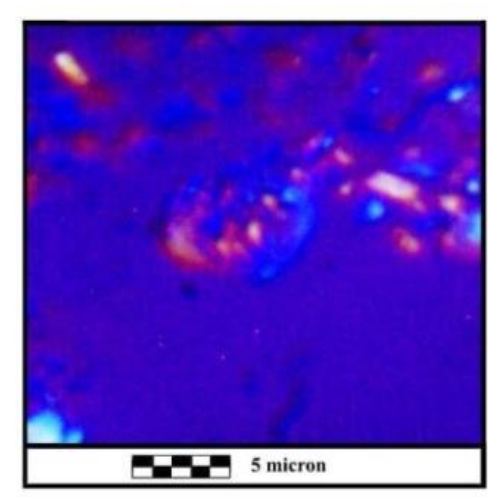

8
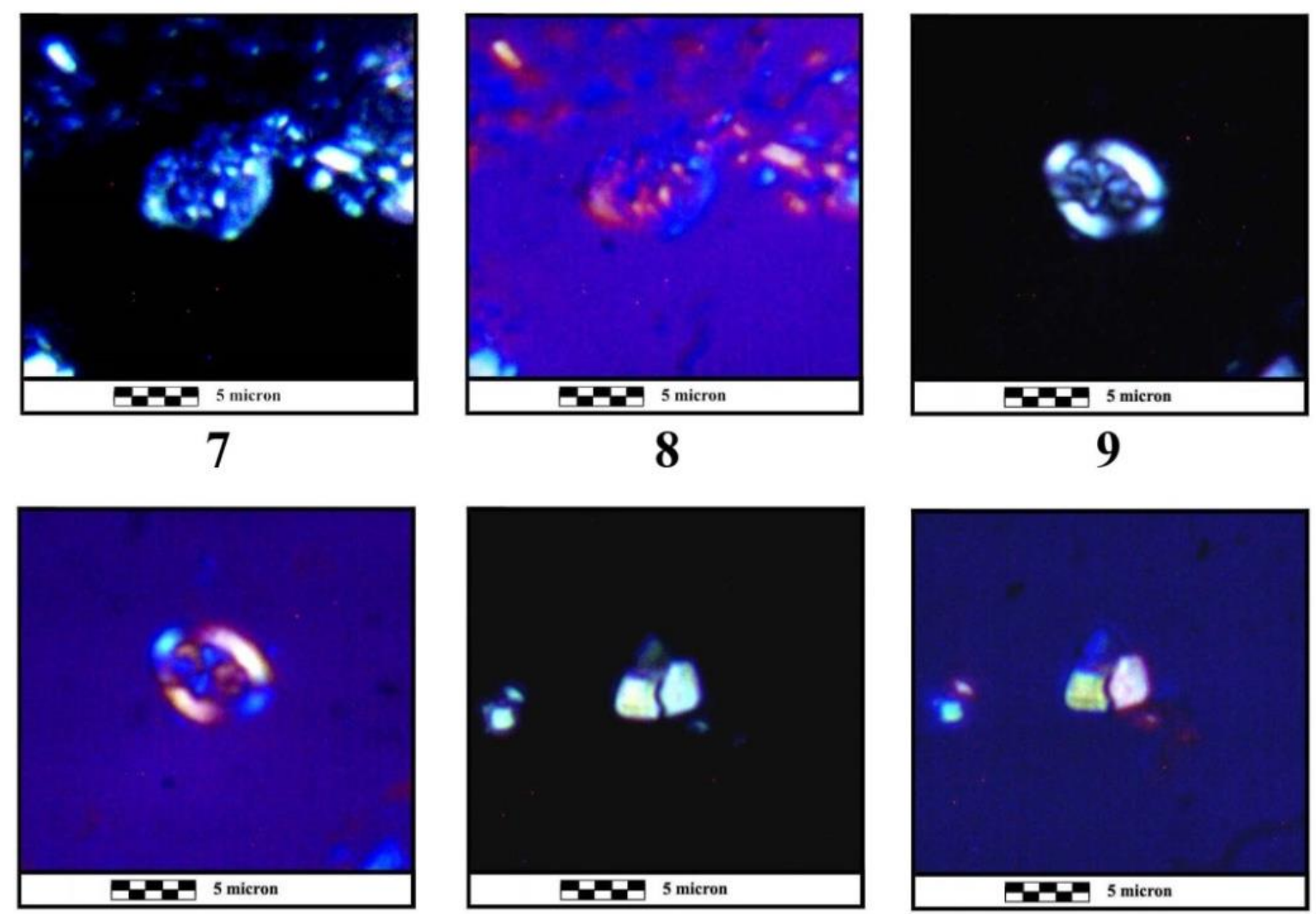

10

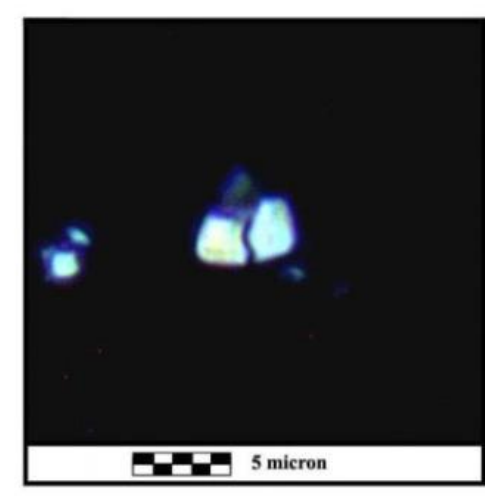

11

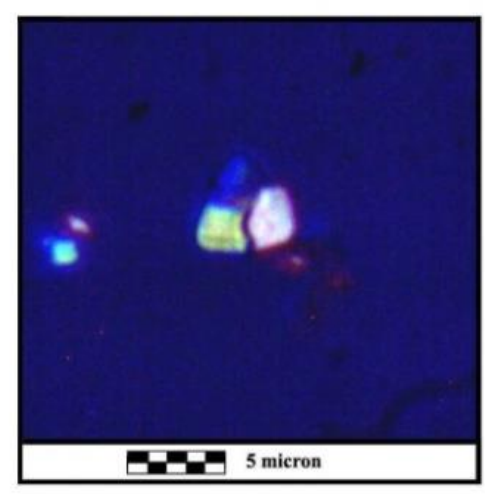

12 